\title{
Experimental Methods to Study Gene Flow
}

\author{
Carol Mallory-Smith, Linda M. Hall, and Nilda R. Burgos*
}

Herbicide resistance is an exceptional marker to quantify gene flow. Quantification of pollen-, seed-, and vegetative propagule-mediated gene flow provides key weed biology information. Pollen-mediated gene flow influences the genetic variance within a population, the frequency of multiple or polygenic herbicide resistance, and the evolutionary dynamics of a species. Seed-mediated gene flow predominates in self-pollinating species. Gene flow quantification may enable the estimation of herbicide resistance epicenter, the comparison of the relative importance of gene flow pathways, and prediction of future distribution of resistance traits. Gene flow studies using herbicide resistance also can provide insight into the rates and importance of hybridization.

Approaches to studying gene flow must consider the biology, breeding system, and dispersal mechanism(s) of the species. We recommend a hypothesis-driven, tiered approach, adopted from an environmental risk assessment for genetically modified crops (Garcia-Alonso et al. 2006; Raybould 2006; Raybould and Cooper 2005; Wolt et al. 2010). General approaches to gene flow studies are outlined, primarily utilizing herbicide resistance as a marker system, but morphological and molecular markers may be required to assist with rapid identification or to identify/confirm hybrids.

A well-constructed quantification of gene flow first organizes existing information on the nature of the resistance trait, the biology of the species (weed or crop), and the mode of inheritance (tier 0 ) (Figure 1). Data are then systematically acquired on frequency and distance of gene flow, moving from small-scale, controlled environments (tier 1) to more variable environments, at a larger scale and sample size (tiers 2 and 3 ). Information gathered in early tiers guides hypothesis development and experimental

\footnotetext{
DOI: $10.1614 /$ WS-D-13-00064.1

* Professor, Department of Crop and Soil Science, Oregon State University, Corvallis, OR 97321; Professor, Agricultural, Food and Nutritional Sciences, 410 Agriculture/Forestry, University of Alberta, Edmonton, Canada T6K 2P5; Professor, Department of Crop, Soil, and Environmental Sciences, University of Arkansas, Fayetteville, AR 72704. Corresponding author's E-mail: Carol.Mallory-Smith@oregonstate.edu
}

design for studies in subsequent tiers. The aim of this chapter is to guide the decision-making process and provide examples of appropriate experimental designs and analysis, recognizing that these may need to be modified on the basis of the species and ecological system. This chapter first outlines information required for problem identification (tier 0 ) and then describes the tiered approach for pollen-, seed-, and vegetative propagule-mediated gene flow. Models of pollen- and seed-mediated gene flow have been reviewed elsewhere (Beckie and Hall 2008; Nathan et al. 2011) and are not addressed here.

Approaches to Study Gene Flow. Tier $O$ Problem Identification. Problem identification is the first step in developing the hypothesis and designing experiments for gene flow quantification. Assemble available information, including reproductive biology, pollen vectors, related species with the potential to hybridize, the nature of inheritance of herbicide resistance, and pre-existing data on gene flow within (intra) and between (inter) species or genera. Information required for seed- or vegetative propagule-mediated gene flow includes dispersal mechanisms and vectors for dispersal. Next, identify information gaps and initiate the collection of missing data. If information is sufficient, research at higher tiers may be initiated.

Gene Flow Tip \#1. Relevant gene flow information may be found in biology, ecology, or phylogenetic literature. Older research should be considered.

Breeding systems must be known because they are correlated with frequency and distance of pollen-mediated gene flow, and population genetic diversity (Barrett 2003). The inheritance of resistance must be determined if not previously established. The population response to a range of herbicide doses must be determined to enable interpretation of inheritance data and used to establish the appropriate screening doses to reliably identify individuals with the resistance marker. 


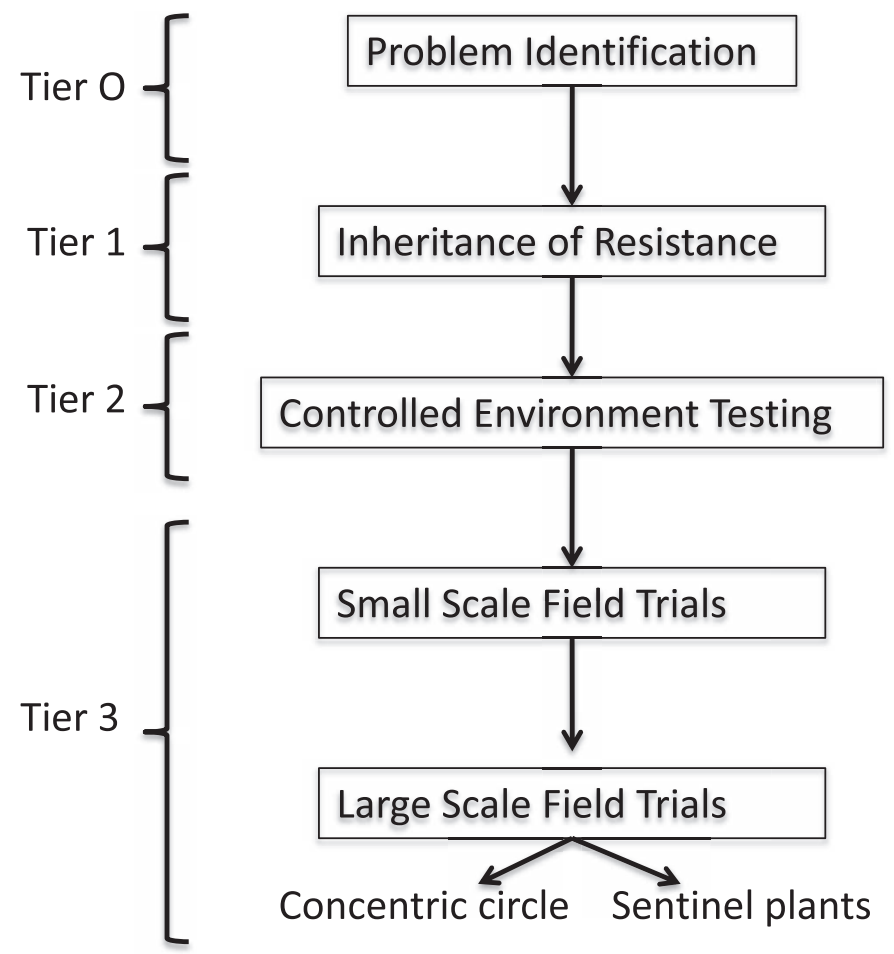

Figure 1. Tier approach to quantification of pollen- and seedmediated gene flow experiments. If information is already available for a tier, it may be skipped and the subsequent tier can begin. The null hypothesis is "gene flow does not occur." If gene flow is not detected in tier 1 or tier 2 (null hypothesis is accepted) or if the distance of gene flow has been captured at a small scale, subsequent experiments may be unnecessary. The "worst-case" nature of tier 1 and tier 2 experiments reduces the opportunity for type II errors, in which the null hypothesis is erroneously accepted. However, if gene flow does occur in tier 1 or tier 2, researchers may choose to quantify gene flow in a more natural situation or at a larger scale.

Step 1. Begin with synthesis of homozygous resistant and susceptible populations. The breeding system determines the methods used to synthesize these populations. In selfing species, seeds collected from a single individual represent a true breeding line and can be created through isolation either in controlled environment conditions or in the field (e.g., use of cages). For obligate outcrossing species, only populations (rather than lines) can be derived.

Gene Flow Tip \#2. Synthesis of homozygous populations for future experiments will allow results to be reported with confidence.

Step 2. Perform reciprocal crosses of pure lines and test the $F_{1}$ populations, along with the parental lines, for level of resistance to the target herbicide after an appropriate dose-response assay (Beckie et al. 2000; Burgos et al. 2013; Seefeldt et al. 1995).
With a dominant or semidominant trait, $F_{1}$ populations respond similarly to the resistant parent. Lack of uniformity among the reciprocal $\mathrm{F}_{1}$ populations suggests (nonnuclear) maternal inheritance; for example see Warwick and Black (1980). Susceptibility of the $F_{1}$ progeny suggests a recessive trait; for example see Zeng and Baird (1997).

Step 3. If the trait appears dominant, perform a backcross of the $\mathrm{F}_{1}$ progeny with the parental line to determine if a single gene confers resistance. Test the progeny using a dose response. The effectiveness of the backcross method to differentiate single gene inheritance from polygenic inheritance depends on herbicide dose (Tabashnik 1991), and polygenic inheritance may be underestimated if the progeny is tested with a single, rather than a complete, dose response (Preston 2003). The null hypothesis is that resistance is controlled by one locus with two alleles. Test this hypothesis using the $\chi^{2}$ goodness of fit.

Gene Flow Tip \#3. For obligate outcrossing species, consider that each individual in the $\mathrm{F}_{1}$ or $\mathrm{F}_{2}$ generation is potentially unique because the offspring accumulates the genetic diversity of each parent.

Through careful screening of $\mathrm{F}_{1}, \mathrm{~F}_{2}$, and backcross generations, the inheritance of resistance and the number of genes and linkage between genes can be determined. However, in the case of resistance conferred by multiple mechanisms, polygenic inheritance or gene amplification, inheritance may be difficult to interpret because of segregation and no simple screening method (Gaines et al. 2010; Manalil et al. 2011; Preston 2003).

Gene Flow Tip \#4. Because the selective dose used for screening influences the relative proportion of individuals scored as susceptible or resistant, a single discriminating dose cannot be used to differentiate polygenic inheritance.

Points to Consider. Resistance to herbicides in more than one chemical group can either be conferred by polygenic or multiple-herbicide resistance mechanisms. In polygenic resistance, multiple genes or loci affecting the same mechanism usually confer cross-resistance via enhanced herbicide metabolism (Chauvel and Gasquez 1994; Letouzé and Gasquez 
2001; Preston 2003), whereas in multiple-herbicide resistance two or more resistance mechanisms are present (Hall et al. 1994). Both mechanisms are more common in outcrossing species, for example in rigid ryegrass (Lolium rigidum Gaudin) (Yu et al. 2007) and blackgrass (Alopecurus myosuroides Huds.) (Hall et al. 1997). Delineating mechanisms is more complex because individuals within these genetically diverse populations may have different combinations of mechanisms. Thus, $\mathrm{F}_{2}$ populations will vary in their response to herbicides so identification and separation of individuals with high resistance and low resistance is required (Tardif and Powles 2006). In the instance of P450-mediated resistance, selection with nonselective or high rates of herbicides may still be used to differentiate plants with stacked resistance genes (Preston 2003). In these instances, a genetic approach may be conducted in concert with confirmation of mechanism(s) of resistance and the type of inheritance.

The inheritance of resistance will drive experimental design for outcrossing. Herbicide resistance conferred by a single dominant gene is an excellent marker, allowing for large-scale screening for gene flow. For recessive, polygenic, or multiple traits, resistance alone is insufficient and will need to be supplemented with morphological or molecular markers.

Gene Flow Tip \#5. A simple and reliable screening method is essential for identification of rare individuals in large populations.

Pollen-Mediated Gene Flow (PMGF). Tiered testing begins with simple artificial scenarios designed to eliminate most factors that may reduce gene flow. The null hypothesis is "Gene flow does not occur." They are not intended to be realistic, but rather to increase the likelihood of detection of gene flow and reduce type II errors. For species where intra- or interspecific gene flow has been quantified, tier 1 testing may be omitted; however, the frequency of gene flow should guide the scale of subsequent experiments.

Tier 1 PMGF: Small-Scale Trials. To test the null hypothesis that gene flow does not occur, reciprocal emasculated crosses should be conducted and compared as described in Hills et al. (2007). To estimate the effectiveness of emasculation, emasculated crosses of both species without pollen transfer also must be conducted. The consistency of emasculation and associated variability will determine the sample number required to refute the null hypothesis. In the case of interspecific hybrids, they may be subject to chromosomal rearrangement and not all traits may be consistently incorporated; herbicide resistance as a marker should be supplemented with morphological or molecular markers to confirm hybridity (Kavanaugh et al. 2010, 2012; Warwick et al. 2003). Replication should be conducted over time as crossability may be affected by greenhouse conditions. Sample size should be established iteratively using a power analysis, following initial experiments. Low-frequency events require higher sample numbers. If no seed are formed, further research is not required. However, negative results are valuable and should be reported.

Gene Flow Tip \#6. Collect data on the relative time to flower for each population/species to assist with flowering synchrony in following experiments.

Tier 2 PMGF: Medium-Scale Trials. If interspecific gene flow has been demonstrated in emasculated crosses, inter- and intraspecific gene flow experiments that include more of the biological barriers to PMGF but maintain an increased likelihood of outcrossing should be initiated. This tier is more realistic and requires increased sample size/power for statistical analysis. The moderate number of seeds allows every seed to be tested; however, at a low frequency of PMGF, the relatively small sample sizes increase the number of replicates with no gene flow. If experiments are analyzed using a simple ANOVA, the absence of variance in zero value makes data analysis problematic. In this instance a power analysis can be used to report a frequency of outcrossing (see below).

Gene Flow Tip \#7. Maximize flowering synchronization between species. This may entail sequential planting of the source species and placing them in the middle of receptor species when both are flowering.

Insect-vectored gene flow. If the pollen vector is an insect, optimize PMGF by using a greenhouse 

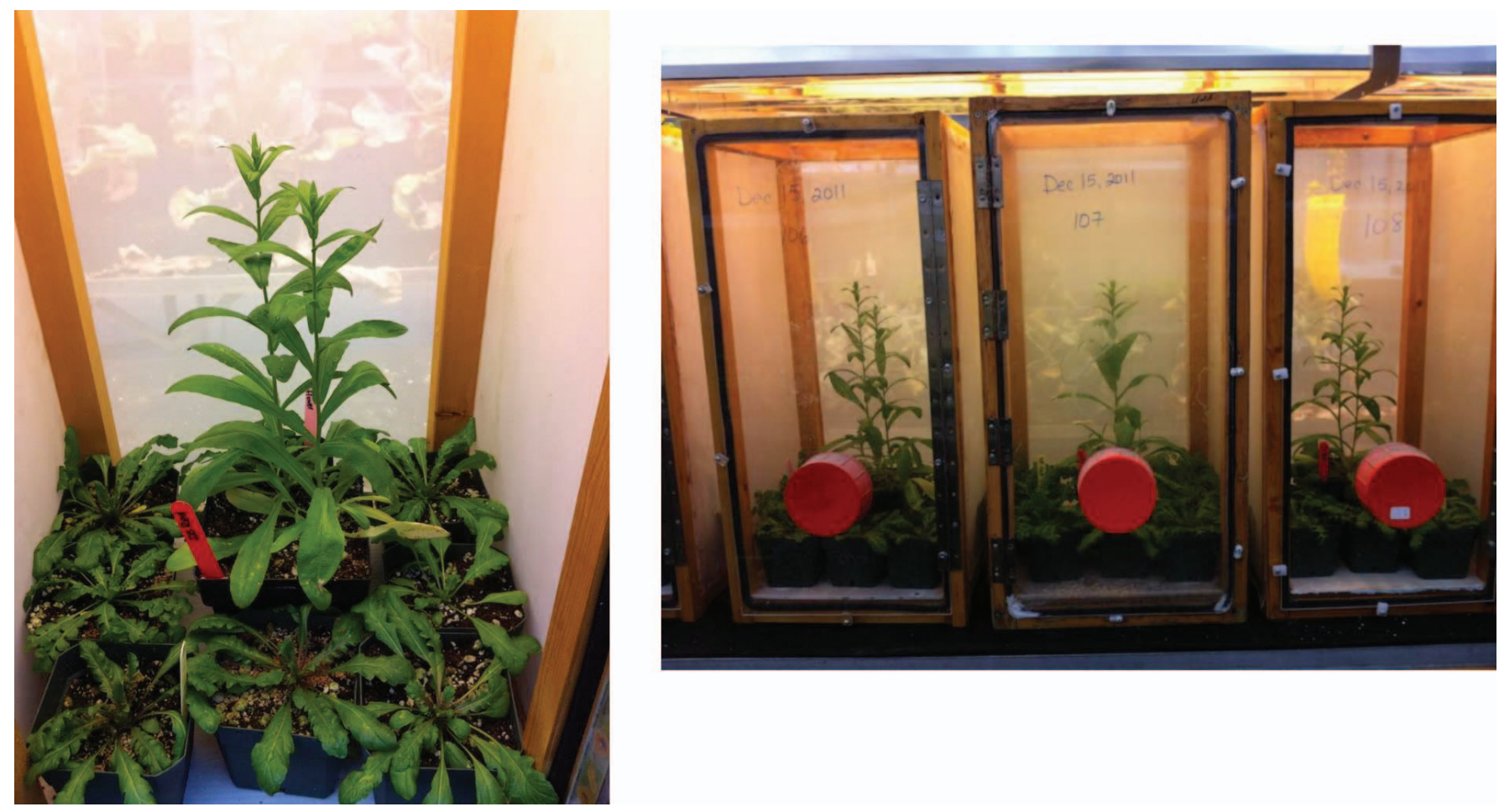

Figure 2. Tier 2 fly-mediated crosses to determine the frequency of intra- or interspecific crossing. These experiments follow tier 1 reciprocal, emasculated hand crosses if gene flow is detected. Potted plants are inserted into the cages before flowering. In this instance, herbicide-resistant Camelina sativa (L.) Crantz is the pollen donor, shephard's-purse [Capsella bursa-pastoris (L.) Medik.] is the receptor, and the putative pollinators used were Delia radicum, common cabbage maggots, a fly commonly observed during flowering periods of crucifer species.

or cages supplemented with appropriate vectors (Figure 2) (Currah and Ockendon 1984). Plant source and receptor species or populations in pots and then place either in cages or greenhouses supplemented with insects. Outcrossing frequency can be calculated using a dominant or incompletely dominant herbicide-resistance trait, either alone or in combination with other markers.

Wind-mediated gene flow. If wind pollination is more likely, small-plot experiments can be conducted either in greenhouses or outdoors. Donor plants can be surrounded with receptor plants, with or without the presence of a crop species (Murray et al. 2002; Walsh et al. 2012). If conducted in a greenhouse, fans can be used to move pollen or pollen source plants can be placed above receptor plants. Test progenies of the receptor plant for herbicide resistance. If detected, quantification of PMGF frequency at a small scale will allow the design of a more complex hypothesis that encompasses both the frequency and distance of outcrossing.

Tier 3 PMGF: Field-Scale Trials. Several experimental plot designs are commonly used for assessing the distance of PMGF: (1) a Nelder wheel (Nelder
1962) or concentric circle designs in which the pollen donor is surrounded with the pollen receptor; (2) an adjacent plot design, used for large donor and receptor blocks where larger-scale pollen donors are required; (3) and sentinel plants, where plots or pots of pollen donors are located at longer distances. For all of these larger-scale experiments, the sequence of planting, tending, and harvesting is critical to reduce sample contamination.

Gene Flow Tip \#8. Seeding and combine/ threshing equipment are two major sources of contamination. Donor seeds should be planted last and donor plants destroyed after flowering before viable seed has set. To reduce contamination, harvest should begin distal to the donor, where gene flow is least, and move toward the donor area.

Nelder wheel. In these field experiments, the pollen donor plants are surrounded by receptor plants, which are divided into direction wedges or arms (Gaines et al. 2007; Hanson et al. 2005; Jhala et al. 2009; McPherson et al. 2009; Stallings et al. 1995b). Depending on the target densities, donor 


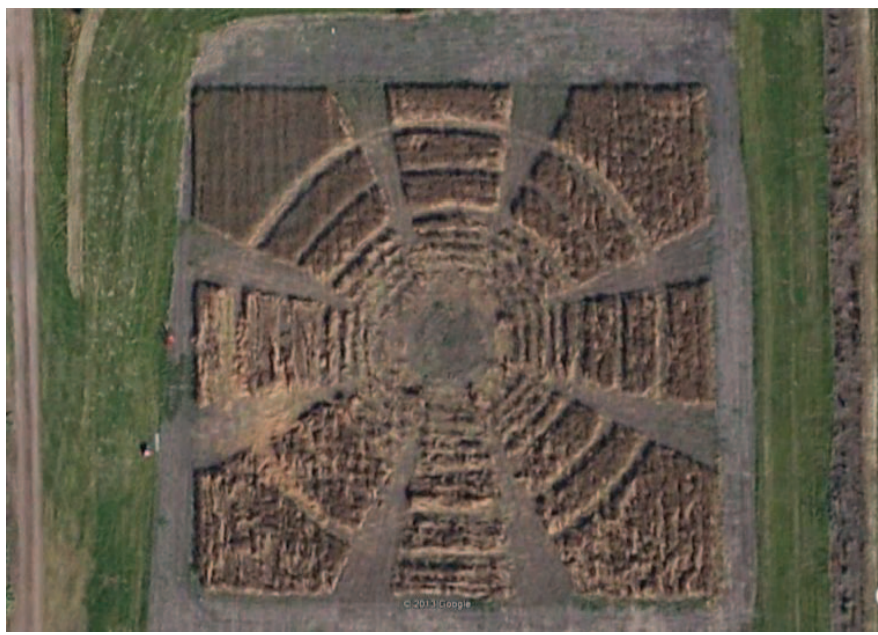

Figure 3. An aerial view of field-scale tier 3 pollen-mediated gene flow experiment, taken after sampling. The homozygous herbicideresistant donor plants were planted in the center, surrounded by susceptible receptor plants. Before harvest, donor plants were removed and the field was divided by mowing into radial arms. Samples were taken from the radial arms at specified distances from the source (lighter areas in the photo). Care must be taken throughout to reduce the inadvertent movement of pollen when plot tending and maintain sample purity at harvest and during screening. The large number of seed necessitates subsampling.

and receptors may either be seeded or transplanted (Stallings et al. 1995b). Although circles are ideal, they are difficult to plant and harvest with mechanical equipment. A more realistic plot layout is an octagon containing the donor surrounded by square of crop with the receptor (Figure 3). Eight directional wedges are delineated after flowering by mowing of areas between the arms to facilitate careful harvest. Mowing after flowering maintains consistent wind and pollinator movement during pollination.

Experiments should be replicated at different locations and years. Gene flow can be modeled as the average frequency over distance and, for comparative purposes, expressed as the distance where gene flow is reduced by 50\% $\left(\mathrm{EX}_{50}\right)$ or $99 \%\left(\mathrm{EX}_{99}\right)$, depending on the value of interest. Directionality of PMGF can be assessed using best linear unbiased predictions, and contrast statements to compare directions (Kavanagh et al. 2012).

Gene Flow Tip \#9. PMGF is leptokurtic in distribution. For efficient sampling of lowfrequency outcrossing events, sample size needs to increase with distance from the pollen source.
Advantages. Sample size increases with circumference of the circle/distance from the source.

Disadvantages. Receptor size is limited and the ratio of donor to receptor plants skewed (Beckie and Hall 2008). To detect low frequencies of gene flow at distance, millions of seeds may need to be screened. Contamination during harvesting can increase the number of false positives.

Adjacent block design. Because the ratio of source and receptor populations is an important factor determining the rate of gene flow, large- or equalsized adjacent blocks (Beckie et al. 2003; Rieger et al. 2002) have been used to determine frequency and distance of gene flow. Sample size is not usually limited; source and receptor populations can be of equal and significant size; information on PMGF distance but not direction can be obtained.

Advantage. For species with long-distance PMGF, extended distances are possible.

Disadvantage. Influence of direction cannot be easily assessed.

Sentinel plants. Another approach to quantify gene flow, appropriate for noncontiguous areas, nonagricultural species, and extreme distances, is to establish and harvest individual sentinel plants as receptors.

Step 1. Establish the trap plants in pots.

Step 2. For landscape field studies, predetermined placement sites can be mapped (Watrud et al. 2004).

Step 3. Place the trap plants at specific distances from the pollen source. Placing the plants within the field provides for the worst-case scenario for crossing to occur, whereas placing outside the pollen source can provide for the measurement at very long distances. Depending on whether the species is wind- or insect-pollinated, placement of the receptor plants might change. If wind-pollinated, increase the number of receptor plants downwind to increase the likelihood of cross-pollination. If insect-pollinated, place the receptor plants closer to pollinator sources, hives or native vegetation.

Step 4. Plant receptor plants at weekly intervals to ensure that flowering time will coincide with the 


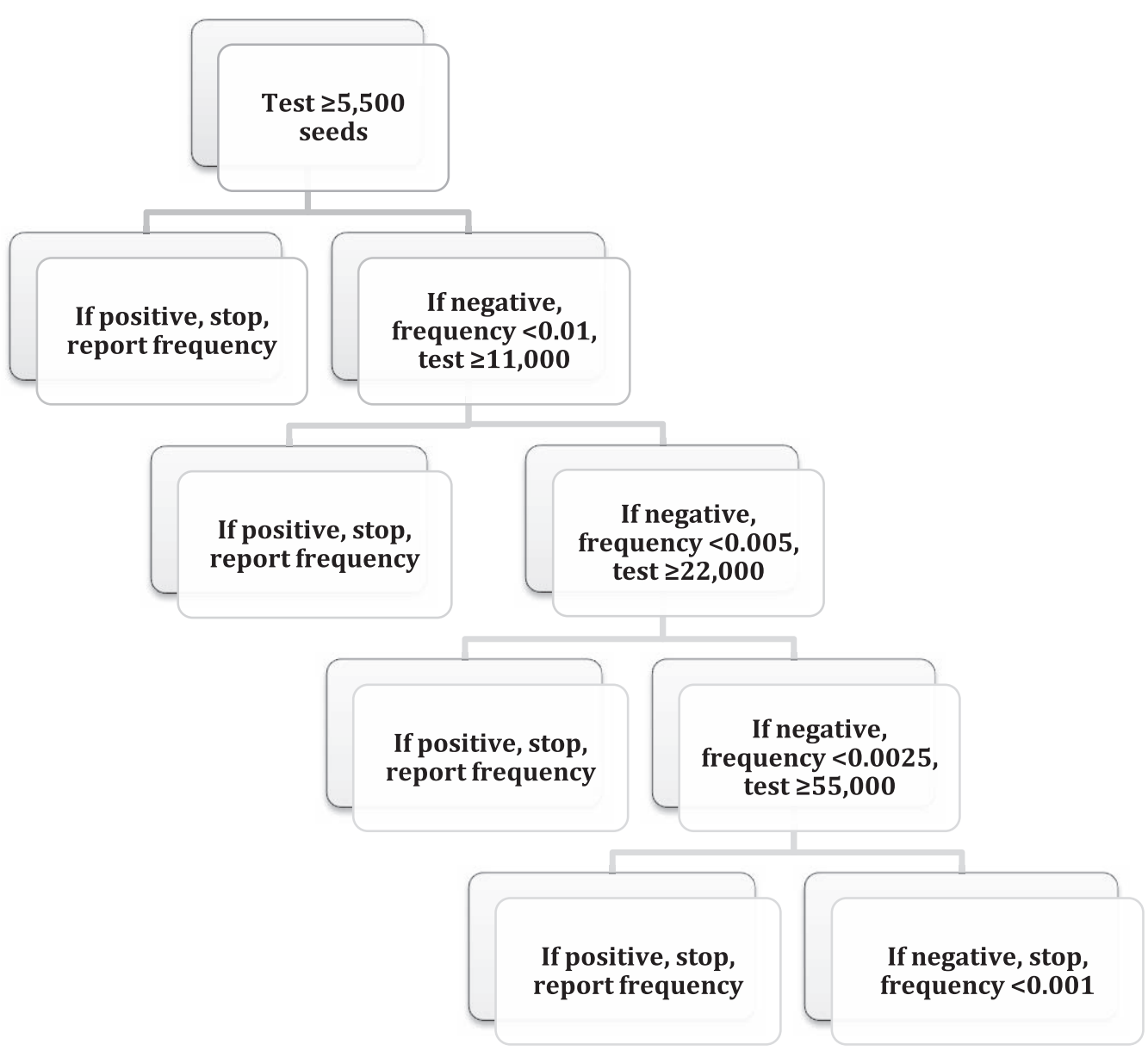

Figure 4. Example of a decision tree for iterative sampling of pollen-mediated gene flow (PMGF) on the basis of a power analysis and a binomial distribution (Jhala et al. 2011; Zar 1999). In this example, a minimum sample size of 5,500 was chosen, on the basis of tiers 1 and 2 experiments that quantified PMGF between adjacent plants at $0.01(1.0 \%)$, and assuming gene flow would diminish distal to the pollen source. If a subsample contains a herbicide-resistant seed, frequency can be reported. If not, subsampling can continue or it may be reported with statistical confidence $(\alpha=0.05$ and at a power of 0.95$)$ to be less than a particular frequency, but not as zero. In this example, if 55,000 seeds have been tested and no resistant seeds identified, the frequency of PMGF is $<0.001(\alpha=0.05$ at a power of 0.95$)$.

pollen donor plants. Plants will then be placed at predetermined sites, but can be replaced if flowering times do not overlap.

Step 5. Monitor receptor plants throughout the pollination period.

Step 6. Once flowering is complete, collect and return the receptor plants to the greenhouse. Remove any new flowers that develop.

Gene Flow Tip \#10. Care must be taken to limit cross-contamination when placing, tending, or retrieving plants. Plants at the outer limits should be monitored first and those closest to the pollen source monitored last.
Points to Consider. The frequency of gene flow determines the appropriate sample size; the lower the frequency, the more individuals that must be assessed to detect at least one resistant individual. The absence of gene flow cannot be demonstrated (except if every individual is tested), and time and resources required to assess a large number of (or all) individuals must be weighed against the accuracy of the information required. A power analysis based on binomial probabilities can be used iteratively to estimate the minimum sample size required to accept the outcome of a statistical test at a certain level of confidence (Kenkel et al. 1989) (Figure 4).

For a sample without resistant individuals, the theoretical frequencies at different $\alpha$ and $\beta$ values serve as a null hypothesis and gene flow frequency can be reported in a statistically meaningful fashion. For example, if 5,544 individuals were sampled and 
no resistant individuals are detected, gene flow can be reported as $<0.01$ at $\alpha=0.05 \%$, for the power of 0.95 (Jhala et al. 2009).

Advantages. Sentinel studies are particularly appropriate when pollen is vectored via wind or insects because they allow for long-distance placement of receptor plants (for example see Busi et al. 2008; Sosnoskie et al. 2012; Zelaya et al. 2007). Because sentinel plants can be placed at great distances from the pollen source, they are easier to manipulate than placing fields of receptor plants or depending on compatible in situ plants to be present at specific distances from the pollen source. Sentinel plants offer the flexibility of placement both in time and distance. The introduction of sentinel plants ensures overlap in flowering time between the pollen donor and pollen receptor plants.

Disadvantages. The use of sentinel plants will decrease the number of potential pollen receptors because of the time and resources needed to place and monitor the individual plants. The absence of a positive sample does not prove that gene flow is absent.

Seed-Mediated Gene Flow (SMGF). Comparatively few studies have evaluated SMGF. A tiered approach and modified experimental designs previously described to study PMGF can be modified to study SMGF. Seed donor plants replace pollen donor plants and seed traps (see discussion on seed traps) replace pollen receptor plants. The choice of methods is dependent on the dispersal vectors. The approaches used for studying seed movement include placement of seed traps, tracking seed spread within a field, and tracking seed spread across the landscape. Seed persistence within the seed bank requires different methodological approaches and is beyond the scope of this document.

\section{Tier 1 SMGF: Small-Scale Trials.}

Gene Flow Tip \#11. Laboratory and windtunnel experiments can rapidly provide information for the scale required for subsequent field experiments and help define appropriate treatments.

Determination of dispersal parameters. For winddispersed seed, data requirements include seed settling velocity in the absence of air movement and the impact of height of seed release and wind speed on movement. Seed settling velocity can be determined by measuring the time for seeds to descend a predetermined distance. Andersen (1992) provides detailed methodology to measure settlement velocity. The distance traveled $(d)$ is a function of the release height $(H)$, wind speed $(U)$, and the terminal velocity of propagule $\left(V_{s}\right)$

$$
d=H U / V_{s}
$$

Determine the appropriate experimental design for the field experiment. Wind-tunnel studies should be used to evaluate the effect of multiple seed release heights and wind speeds on seed movement (Dauer et al. 2006). The data generated can be used to construct models to better define the field experimental design appropriate for a particular species.

Determine the appropriate seed trap. Preliminary seed-trap studies should be conducted to choose which material would work best for the species studied. Sticky traps, funnel traps, and pots or trays with soil or versions of these traps have been used to study seed dispersal (Chabrerie and Alard 2005; Cottrell 2004). Page et al. (2002) discusses the advantages and disadvantages of different trap types. The number of traps needed must also be estimated.

Advantage. The relative rapidity of initial experiments in controlled conditions permits a wide range of variable to be assessed.

Tier 2 SMGF Small-Scale Trials.

Gene Flow Tip \#12. Seed sampling efforts should increase with distance to quantify rare long-distance dispersal.

Seed dispersal experiments for most species can be conducted at relatively short distances and replicated in different locations. Seed collection methods include trays, or vacuuming of the soil surface. The landscape will need to be surveyed for the presence of the species studied. If the species already exists in the area, the study of seed movement is compromised (Zapiola et al. 2007) unless a unique genetic marker (i.e., herbicide resistance) or morphological marker can be used. 
Tier 3 SMGF: Field-Scale Trials.

Wind-vectored seed dispersal. Long-distance airborne seed movement was measured for Conzya canadensis (L.) using radio-controlled aircraft (Dauer et al. 2007; Dauer et al. 2009; Shields et al. 2006). Seed traps were placed on the planes carrying data loggers to record location, altitude, and ground and air speed. The collecting surfaces were sprayed with a sticky adhesive to capture seeds that came in contact with the trap. The use of aircraft allowed seed to be collected at different heights as well as distances. In addition to the aircraft, ground towers were constructed and fit with sticky traps to collect seed near ground level (Dauer et al. 2009). These studies allow measurement of seed dispersal from plants in real time rather than measuring the seed deposition.

Tumbling species (i.e., tumbleweeds) present a different challenge because plants release seed over the distance traveled. Two field methods have been described for measuring seed dispersal from tumbling species (Baker et al. 2010; Stallings et al. $1995 \mathrm{a}, \mathrm{b})$. In one case, plants were grown in a common garden, tagged, released, tracked, and collected over time (Stallings et al. 1995a). Natural barriers to plant dispersal were used in this study. In the other study, fences were erected to trap the plants (Baker et al. 2010). In situ plants were selected, tagged, painted, and the location georeferenced. Seed dispersal over distance can be calculated as the seed that remains on the plant vs. the estimated seed on a plant before dispersal (Baker et al. 2010; Stallings et al. 1995a). Field studies can be combined with controlled-environment windtunnel studies to predict seed loss over distance at a particular wind speed (Baker et al. 2010).

Mechanical vectored seed dispersal. To quantify the movement of weed seeds by mechanical harvest dispersal Blanco-Moreno et al. (2004) and Shirtliffe and Entz (2005) planted a strip of weeds perpendicular to crop plots. Weed fecundity was measured and the crop was either harvested or windrowed at maturity. Weed seeds expelled from the harvester were sampled from seed traps placed at intervals along the direction of travel of the combine. Seed traps were placed in parallel, immediately behind the combine to catch chaff and alongside to catch seeds lost in the straw fraction. An alternative method appropriate for small seeds is to vacuum the soil surface to determine a density. Weed seed captured in the harvest grain could have been assessed by separation of weed and crop seed. Weed seed retention in combine harvests can be determined by cleaning and collection of seeds in combines; however, the dispersal of those seeds would be much more problematic to quantify because of the random nature of dislodging over transport and subsequent harvest activities.

To quantify horizontal seed dispersal by tillage, colored beads, global positioning system transponders, and seeds of crops and weeds have been used as markers and treatments applied. Colored beads simulating weed seeds can be place either on the soil surface, or using augers, different colored beads can be placed at various depths (Mead et al. 1998; RogerEstrade et al. 2001). After treatments beads can be recovered in soil cores (Rew and Cussans 1997). Passive integrated transponders (PITs) are small microchips that use radiofrequency identification technology (Wilson et al. 2010). They have a unique identification code that can be read with a handheld scanner transceiver. Wilson et al. (2010) tested PITs of varying sizes ( 11.5 to $22 \mathrm{~mm}$ by $2 \mathrm{~mm}$ ) in depths of water, and soil of several types, enclosed in nylon mesh and unprotected over $2 \mathrm{yr}$. They reported that PITs were $85 \%$ recoverable after $2 \mathrm{yr}$ and that they may be useful to study seed movement, especially as recovery technologies improve and size decreases. In some instances, nondormant crop seeds are used to simulate weed seeds and their position indicated by emergence of seedlings (Davis and Luschei 2009; Grundy et al. 1999;). Weed seeds also have been used for a more realistic but labor-intensive study of seed movement (Grundy and Mead 1998). The use of crop or weed seed emergence to examine movement is confounded by the influence of depth, seed predation, and seed dormancy. Complete seed recovery is not feasible with these methods, and rare, long-distance seed movement may fail to be captured.

Advantages. The variability of seed dispersal can be captured in these experiments. Seed life is longer than pollen or vegetative propagules so it is possible to study movement over time.

Disadvantages. Because of the spatial nature of weed seed distribution and the role of random events, variability is high. If tillage is one of the factors in the study, seed extraction and seed identification are time consuming.

Points to consider. It is useful to estimate seed production before distribution to determine the 
success of seed capture. For accurate data, seed sampling must occur before seed is lost through predation or germination.

\section{Vegetative Propagule-Mediated Gene Flow} (VPMGF). There are few methods published on movement of vegetative propagules. However, VPMGF has the potential to contribute significantly to gene movement in the environment. Vegetative propagules vary greatly in their structure. Vegetative propagules include roots, rhizomes, stolons, tubers, bulbs, and similar underground structures, bulbils. Bulbs, tubers, and similar structures will generally be viable for a longer period than roots, rhizomes, and stolons. Therefore, study duration and distance likely will vary on the basis of the structure. One fact to consider when designing experiments is that vegetative propagules are clones of the plant from which they originated.

Step 1. Conduct preliminary studies using controlled environment to determine the life span of propagules under different conditions. The distance by which a species can spread via vegetative propagules depends on the life span of these materials. Thus, the effects of temperature, burial, drying, wetting, or submersion on propagule viability and longevity need to be determined before conducting field studies.

Step 2. Determine the type of traps to use in collecting vegetative propagules.

Step 3. Conduct a preliminary study of the potential routes, agents, and distance of dispersal. Consider these factors in designing the experiment.

Sampling for VPMGF. There are no established general protocols for collecting samples to detect VPMGF. Nevertheless, we can glean some guidance from studies on the spread of the species giant reed (Arundo donax L.) in Australia (Haddadchi et al. 2013), Italy (Mariani et al. 2010), and the United States (Khudamrongsawat et al. 2004).

Step 1. On the basis of information obtained from background research mentioned above, determine the potential route of dispersal and geographic range to be sampled. If the propagules are potentially dispersed by water via rivers or irrigation systems, use geographic information system data to generate an overview of the area to be sampled. Do the same for potential dispersal via road networks or railroad tracks.
Step 2. On the basis of available resources (financial, labor, facilities, and equipment), determine the number of samples that can be collected and analyzed. With a predominantly clonal species such as Arundo spp., each distinct patch is genetically identical and can be represented by one plant sample. Consult with a statistician to ensure that an appropriate number of samples is collected to conduct proper data analysis.

Step 3. Determine the minimum separation distance between samples. In Australia for example, 15 stands of the sterile giant reed were sampled across $37,000 \mathrm{~km}^{2}$, encompassing catchment areas of three river systems (see Haddadchi et al. 2013 for details). A stand is comprised of a single or multiple distinct patches across a 2-km stretch of river. Each stand was at least $10 \mathrm{~km}$ apart. The number of plants sampled in each stand ranged from 1 to 16 , depending on the size of the stand and the number of distinct patches within a stand. In the United States, any stand large enough to sample along the Santa Ana River (in California) from the headwaters to the ocean was considered a sampling site, resulting in a minimum distance of $3.2 \mathrm{~km}$ between sampling sites (Khudamrongsawat et al. 2004).

Step 4. Use the appropriate resistance trait marker and genomic molecular markers (e.g., AFLP, intersimple sequence repeats, simple sequence repeats) to confirm if gene flow occurred via clonal dispersal or by sexual means.

Conclusion. A tiered approach to quantification of gene flow results in experiments designed at the appropriate scale and sample size. In some instances, only greenhouse or short-distance experiments are required. Preliminary data gathering and experimentation are excellent investments when largescale experiments may require a growing season to implement and then months to screen the millions of seeds for rare individuals.

\section{Literature Cited}

Andersen MC (1992) An analysis of variability in seed settling velocities of several wind-dispersed Asteraceae. Am J Bot 79 (10):1087-1091

Baker DV, Withrow JR, Brown CS, Beck KG (2010) Tumbling: use of diffuse knapweed (Centaurea diffusa) to examine an understudied dispersal mechanism. Invas Plant Sci Mar 3:301-309

Barrett SCH (2003) Mating strategies in flowering plants: the outcrossing-selfing paradigm and beyond. Phil Trans R Soc London Ser B Biol Sci 358:991-1004 
Beckie HJ, Hall LM (2008) Simple to complex: modelling crop pollen-mediated gene flow. Plant Sci 175:615-628

Beckie HJ, Heap IM, Smeda RJ, Hall LM (2000) Screening for herbicide resistance in weeds. Weed Technol 14:428-445

Beckie HJ, Warwick SI, Nair H, Seguin-Swartz G (2003) Gene flow in commercial fields of herbicide-resistant canola (Brassica napus). Ecol Appl 13:1276-1294

Blanco-Moreno JM, Chamorro L, Masalles RM, Recasens J, Sans FX (2004) Spatial distribution of Lolium rigidum seedlings following seed dispersal by combine harvesters. Weed Res 44:375-387

Burgos NR, Tranel PJ, Streibig JC, Davis VM, Shaner D, Norsworthy JK, Ritz C (2013) Review: confirmation of resistance to herbicides and evaluation of resistance levels. Weed Sci 6:4-20

Busi R, Yu Q, Barrett-Lennard R, Powles S (2008) Long distance pollen-mediated flow of herbicide resistance genes in Lolium rigidum. Theor Appl Gen 117:1281-1290

Chabrerie O, Alard D (2005) Comparison of three seed trap types in a chalk grassland: Toward a standardised protocol. Plant Ecol 176:101-112

Chauvel B, Gasquez J (1994) Relationships between genetic polymorphism and herbicide resistance within Alopecurus myosuroides huds. Heredity 72:336-344

Cottrell TR (2004) Seed rain traps for forest lands: considerations for trap construction and study design. BC J Ecosyst Manag 5:1-6

Currah L, Ockendon DJ (1984) Pollination activity of blowflies and honeybees on onions in breeders' cages. Ann Appl Biol 105:167-176

Dauer JT, Mortensen DA, Humston R (2006) Controlled experiments to predict horseweed (Conyza canadensis) dispersal distances. Weed Sci 54:484-489

Dauer JT, Mortensen DA, Luschei EC, Isard SA, Shields E, VanGessel MJ (2009) Conyza canadensis seed ascent in the lower atmosphere. Agric Forest Meteorol 149:526-534

Dauer JT, Mortensen DA, Van Gessel MJ (2007) Temporal and spatial dynamics of long-distance Conyza canadensis seed dispersal. J Appl Ecol 44:105-114

Davis AS, Luschei EC (2009) Living boundaries: tracking weed seed movement with nondormant seed. Weed Sci 57:163-168

Gaines TA, Byrne PF, Westra P, Nissen SJ, Henry WB, Shaner DL, Chapman PL (2007) An empirically derived model of field-scale gene flow in winter wheat. Crop Sci 47:2308-2316

Gaines TA, Vencill WK, Sammons RD, Grey TL, Webster TM, Leach JE, Westra P, Jiang J, Preston C, Culpepper AS, Bukun B, Chisholm ST, Zhang W, Wang D, Patzoldt WL, Tranel PJ, Shaner DL, Nissen SJ (2010) Gene amplification confers glyphosate resistance in Amaranthus palmeri. Proc Natl Acad Sci U S A 107:1029-1034

Garcia-Alonso M, Jacobs E, Raybould A, Nickson TE, Sowig P, Willekens H, Van Der Kouwe P, Layton R, Amijee F, Fuentes AM, Tencalla F (2006) A tiered system for assessing the risk of genetically modified plants to non-target organisms. Environ Biosafety Res 5:57-65

Grundy A, Mead A (1998) Modelling the effects of seed depth on weed seedling emergence. Asp Appl Biol 51:75-82

Grundy A, Mead A, Burston S (1999) Modelling the effect of cultivation on seed movement with application to the prediction of weed seedling emergence. J Appl Ecol 36:663-678

Haddadchi A, Gross CL, Fatemi M (2013) The expansion of sterile Arundo donax (Poaceae) in southeastern Australia is accompanied by genotypic variation. Aquatic Bot 104: $153-161$

Hall L, Moss S, Powles S (1997) Mechanisms of resistance to aryloxyphenoxypropionate herbicides in two resistant biotypes of Alopecurus myosuroides (blackgrass): herbicide metabolism as a cross-resistance mechanism. Pestic Biochem Physiol 57:87-98

Hall L, Tardif FJ, Powles SB (1994) Mechanisms of cross and multiple herbicide resistance in Alopecurus myosuroides and Lolium rigidum. Phytoprotection 75:17-23

Hanson BD, Mallory-Smith CA, Shafii B, Thill DC, Zemetra RS (2005) Pollen-mediated gene flow from blue aleurone wheat to other wheat cultivars. Crop Sci 45:1610-1617

Hills MJ, Hall LM, Messenger DF, Graf RJ, Beres BL (2007) Evaluation of crossability between triticale (X triticosecale wittmack) and common wheat, durum wheat and rye. Environ Biosafety Res 6:249-257

Jhala AJ, Bhatt H, Topinka K, Hall LM (2011) Pollen-mediated gene flow in flax (Linum usitatissimum L.): Can genetically engineered and organic flax coexist? Heredity 106:557-566

Jhala AJ, Hall LM, Hall JC (2008) Potential hybridization of flax (Linum usitatissimum L.) with weedy and wild relatives: an avenue for movement of engineered genes? Crop Sci 48:825-840

Kavanaugh V, Hall LM, Hall J (2010) Potential hybridization of genetically engineered triticale with wild and weedy relatives in Canada. Crop Sci 50:1128-1140

Kavanagh VB, Hills MJ, Eudes F, Topinka K, Yang R, Hall LM (2012) Pollen-mediated gene flow in triticale. Crop Sci 52:2293-2303

Kenkel NC, Juhasz-Nagy P, Podani J (1989) On sampling procedures in population and community ecology. Vegetatio 83:195-207

Khudamrongsawat J, Tayyar R, Holt JS (2004) Genetic diversity of giant reed (Arundo donax) in the Santa Ana River, California. Weed Sci 52:395-405

Letouzé A, Gasquez J (2001) Inheritance of fenoxaprop-P-ethyl resistance in a blackgrass (Alopecurus myosuroides huds.) population. Theor Appl Gen 103:288-296

Manalil S, Busi R, Renton M, Powles SB (2011) Rapid evolution of herbicide resistance by low herbicide dosages. Weed Sci 59:210-217

Mariani C, Cabrini R, Danin A, Piffanelli P, Fricano A, Gomarasca S, Dicandilo M, Grassi F, Soave C (2010) Origin, diffusion and reproduction of the giant reed (Arundo donax L.): a promising weedy energy crop. Ann Appl Biol 157: 191-202

McPherson MA, Good AG, Topinka AKC, Hall LM (2004) Theoretical hybridization potential of transgenic safflower (Carthamus tinctorius L.) with weedy relatives in the new world. Can J Plant Sci 84:923-934

McPherson MA, Good AG, Topinka AKC, Yang RC, McKenzie RH, Cathcart JR, Christianson JA, Strobeck C, Hall LM (2009) Pollen-mediated gene flow from transgenic safflower (Carthamus tinctorius) intended for plant molecular farming to conventional safflower. Environ Biosafety Res 8:19-32

Mead A, Grundy A, Burston S (1998) Predicting the movement of seeds following cultivation. Asp Appl Biol 55:91-98

Murray BC, Morrison IN, Friesen LF (2002) Pollen-mediated gene flow in wild oat. Weed Sci 50:321-325

Nathan R, Katul GG, Bohrer G, Kuparinen A, Soons MB, Thompson SE, Trakhtenbrot A, Horn HS (2011) Mechanistic models of seed dispersal by wind. Theor Ecol 4:113-132 
Nelder JA (1962) New kinds of systematic designs for spacing experiments. Biometrics 18:283-307

Page MJ, Newlands L, Eales J (2002) Effectiveness of three seedtrap designs. Aust J Bot 50:587-594

Preston C (2003) Inheritance and linkage of metabolism-based herbicide cross-resistance in rigid ryegrass (Lolium rigidum).

Weed Sci 51:4-12

Raybould A (2006) Problem formulation and hypothesis testing for environmental risk assessments of genetically modified crops. Environ Biosafety Res 5:119-125

Raybould A, Cooper I (2005) Tiered tests to assess the environmental risk of fitness changes in hybrids between transgenic crops and wild relatives: the example of virus resistant Brassica napus. Environ Biosafety Res 4:127-140

Rew L, Cussans G (1997) Horizontal movement of seeds following tine and plough cultivation: implications for spatial dynamics of weed infestations. Weed Res 37:247-256

Rieger MA, Lamond M, Preston C, Powles SB, Roush RT (2002) Pollen-mediated movement of herbicide resistance between commercial canola fields. Science 296:2386-2388

Roger-Estrade J, Colbach N, Leterme P, Richard G, Caneill J (2001) Modelling vertical and lateral weed seed movements during mouldboard ploughing with a skim-coulter. Soil Tillage Res 63:35-49

Seefeldt SS, Jensen JE, Fuerst EP (1995) Log-logistic analysis of herbicide dose-response relationships. Weed Technol 9:218-227

Shields EJ, Dauer JT, VanGessel MJ, Neumann G (2006) Horseweed (Conyza canadensis) seed collected in the planetary boundary layer. Weed Sci 54:1063-1067

Shirtliffe SJ, Entz MH (2005) Chaff collection reduces seed dispersal of wild oat (Avena fatua) by a combine harvester. Weed Sci 53:465-470

Sosnoskie LM, Webster TM, Kichler JM, MacRae AW, Grey TL, Culpepper AS (2012) Pollen-mediated dispersal of glyphosate-resistance in Palmer amaranth under field conditions. Weed Sci 60:366-373

Stallings GP, Thill DC, Mallory-Smith CA, Lass LW (1995a) Plant movement and seed dispersal of Russian thistle (Salsola iberica). Weed Sci 43:63-69

Stallings GP, Thill DC, Mallory-Smith CA, Shafil B (1995b) Pollen-mediated gene flow of sulfonylurea-resistant kochia (Kochia scoparia). Weed Sci 43:95-102

Tabashnik BE (1991) Determining the mode of inheritance of pesticide resistance with backcross experiments. J Econ Entomol 84:703-712
Tardif FJ, Powles SB (2006) Herbicide multiple-resistance in a Lolium rigidum biotype is endowed by multiple mechanisms: isolation of a subset with resistant acetyl-CoA carboxylase. Physiol Plant 91:488-494

Walsh KD, Puttick DM, Hills MJ, Yang RC, Topinka KC, Hall LM (2012) Short communication: first report of outcrossing rates in camelina [Camelina sativa (L.) crantz], a potential platform for bioindustrial oils. Can J Plant Sci 92:681-685

Warwick S, Black L (1980) Uniparental inheritance of atrazine resistance in Chenopodium album. Can J Plant Sci 60:751-753

Warwick SI, -Simard M, Légère A, Beckie HJ, Braun L, Zhu B, Mason P, Séguin-Swartz G, Stewart CN (2003) Hybridization between transgenic Brassica napus L. and its wild relatives: Brassica rapa L., Raphanus raphanistrum L., Sinapis arvensis L., and Erucastrum gallicum (willd.) O.E. schulz. Theor Appl Gen 107:528-539

Watrud LS, Lee EH, Fairbrother A, Burdick C, Reichman JR, Bollman M, Storm M, King G, van De Waters PK (2004) Evidence for landscape-level, pollen-mediated gene flow from genetically modified creeping bentgrass with CP4 EPSPS as a marker. Proc Natl Acad Sci U S A 101:14533-14538

Wilson DW, Sbatella GM, Wang QQ, Miller SD (2010) Suitability of passive integrated transponder (PIT) tags for tracking weed seed movement in soils. Weed Technol 24:386-391

Wolt J, Keese P, Raybould A, Fitzpatrick J, Burachik M, Gray A, Olin SS, Schiemann J, Sears M, Wu F (2010) Problem formulation in the environmental risk assessment for genetically modified plants. Transgen Res Pp 425-436

Yu Q, Cairns A, Powles S (2007) Glyphosate, paraquat and ACCase multiple herbicide resistance evolved in a Lolium rigidum biotype. Planta 225:499-513

Zar JH (1999) Biostatistical Analysis. 4th ed. Upper Saddle River, New Jersey: Prentice-Hall, Inc. 663 p

Zapiola M, Campbell C, Butler M, Mallory-Smith C (2007) Escape and establishment of transgenic glyphosate-resistant creeping bentgrass (Agrostis stolonifera) in Oregon, USA: a 4year study. J Appl Ecol 45:486-494

Zelaya IA, Owen MD, VanGessel MJ (2007) Transfer of glyphosate resistance: evidence of hybridization in Conyza (Asteraceae). Am J Bot 94:660-673

Zeng L, Baird W (1997) Genetic basis of dinitroaniline herbicide resistance in a highly resistant biotype of goosegrass (Eleusine indica). J Hered 88:427-432

Received April 24, 2013, and approved September 18, 2013. 